\title{
Meat quality and sensory attributes of Orpington and indigenous Tswana chickens reared under intensive system from day old to 18 weeks of age
}

\author{
Malebogo Virginia Radikara, John Cassius Moreki ${ }^{\star}$, Patrick Monametsi Kgwatalala, \\ Molebeledi Horatius Dambe Mareko and James Bashi Machete
}

\author{
Department of Animal Science and Production, Botswana University of Agriculture and Natural Resources, Botswana. \\ *Corresponding author. E-mail: jcmoreki@gmail.com. Tel: +267 3928831. Fax: +267 3928753. \\ Copyright () 2016 Radikara et al. This article remains permanently open access under the terms of the Creative Commons Attribution License 4.0, \\ which permits unrestricted use, distribution, and reproduction in any medium, provided the original work is properly cited.
}

Received 13th August, 2016; Accepted 6th September, 2016

\begin{abstract}
This study was carried out to compare meat characteristics of Tswana and Orpington chickens. A total of 120 chicks (60 Tswana and 60 Orpington) were reared intensively up to 18 weeks of age. Each treatment (Tswana and Orpington) was replicated four times with 15 birds per replicate. Birds were provided with commercial broiler diets and water ad libitum. A total of 40 (10 birds/ replicate) randomly selected chickens of each genotype (Orpington and Tswana) were sacrificed at 18 weeks of age and their carcasses cut into primal parts. Left breast and thigh portions were used for $\mathrm{pH}$, colour and tenderness measurements. The right breast and thigh portions were subjected to sensory evaluation where a 9-point Hedonic scale was used to determine overall liking and disliking of juiciness, flavour and acceptability of meat by untrained panelists. Breast meat samples were in unsalted water for 30 minutes and thigh for 25 minutes. Meat colour, $\mathrm{pH}$ and tenderness were analysed using General Linear Model (GLM) procedure of the Statistical Analysis System while data on sensory attributes were analysed using frequencies and percentages in IBM SPSS. Thigh meat $\mathrm{pH}$ was significantly higher $(\mathrm{P}<0.05)$ in Orpington than Tswana chickens. However, no significant difference $(\mathrm{P}>0.05)$ in breast muscle $\mathrm{pH}$ was found among genotypes. Orpington breast meat was lighter $(\mathrm{P}<0.05)$ than Tswana chicken meat. No significant $(P>0.05)$ difference in breast and thigh meat colour redness $\left(a^{*}\right)$, and yellowness $\left(b^{*}\right)$ was observed. Thigh meat of Tswana chickens was firmer $(\mathrm{P}<0.05)$ compared to Orpingtons. For overall acceptance $50 \%$ of consumers liked Tswana chicken meat compared to $20 \%$ for Orpington meat.
\end{abstract}

Key words: Genotype, meat characteristics, untrained panelists.

\section{INTRODUCTION}

Rearing system affects quality of poultry meat (Bogosavljević-Bosković et al., 2006). An important aspect of meat quality is eating quality, normally referred to as scores outlined by taste panelists for tenderness, juiciness and flavour. These attributes are affected by several production factors (i.e., breed or slaughter age) and by intrinsic animal factors such as muscle type (red or white) and intramuscular lipid content (Baeza et al., 2010). In poultry, the influence of carcass fatness on muscle lipid content and sensory quality of meat depends on the species (Berri et al., 2005). Consumer tastes and preferences are determined by several factors some of which may be related to chicken meat quality while others are inherent in the individual consumer personality. Production factors such as age, sex, genotype, diet, stocking density, method of slaughter, and post-slaughter factors (e.g., cooking method) may affect poultry meat texture and flavour (Northcutt, 2009). These factors may affect the composition of raw meat and the progress of flavour forming reactions during cooking.

Indigenous chicken breeds play an important role in the economic development of rural communities with respect to their subsidiary income and provide them with nutritious eggs and meat for their consumption by 
contributing to the national supply of meat and eggs (Kgwatalala et al., 2012; Padhi, 2016). The challenge associated with rearing family chickens is low productivity (Weyuma et al., 2015) and this challenge has brought a major threat to family chickens as they are being replaced by the highly productive and/or large-sized exotic chicken breeds/strains such as the Orpington and the Australorp. Therefore, this study was carried out to compare meat quality and sensory attributes of Tswana and Orpington chickens at 18 weeks of age raised under intensive production system.

\section{MATERIALS AND METHODS}

\section{Study site}

One day old Tswana and Orpington chicks were obtained from local farmers around Gaborone and raised at Botswana University of Agriculture and Natural Resources (BUAN). The area is located at an altitude of $994 \mathrm{~m}$ above sea level. The coordinates are latitude $24^{\circ}$ $33^{`} \mathrm{~S}$ and longitude $25^{\circ} 54^{\circ} \mathrm{E}$. The study was carried out from September 2014 to January 2015 and the average temperature during the study period was $35.5^{\circ} \mathrm{C}$. Sensory evaluation was performed in the Meat Science Laboratory at BUAN.

\section{Experimental birds and their management}

A total of 120 chicks (60 Tswana and 60 Orpington) were reared up to 18 weeks of age under intensive system. Each treatment (Tswana and Orpington) was randomly replicated four times with 15 birds per replicate. Birds were provided with pre-weighed chick broiler starter crumbs from day old to 4 weeks of age and broiler grower pellets from 5 to 18 weeks of age. Feed and water were provided ad libitum throughout the experimental period.

\section{Sample preparations}

At 18 weeks of age 40 birds (10 birds/replicate) were randomly selected chickens from each genotype (Orpington and Tswana) and mechanically stunned at BUAN slaughterhouse followed by severing the carotid arteries and jugular veins and draining of blood under gravity. Birds were scalded to facilitate mechanical plucking and thereafter manually eviscerated. The carcasses were then cut into portions/primal parts as described by Kleczek et al. (2000) and the weight of individual cuts determined using electronic balance sensitive to $0.001 \mathrm{~g}$. Thereafter, samples were kept frozen at $-8^{\circ} \mathrm{C}$ until analyses were performed.

\section{Data collection}

Approximately 24 hours prior to meat quality determina- tions, left breast and thigh portions were placed in a cold room to facilitate thawing. On the morning of analyses, carcasses still in their original shrink wrapping were immersed in cold water for approximately 30 minutes to complete the thawing process. The $\mathrm{pH}$ was measured on whole raw breast and thigh meat directly by placing a $\mathrm{pH}$ probe (Hanna Instruments; Portable Water Proof Meat $\mathrm{pH}$ meter H199163) directly into the meat of the two chicken types. Meat colour was determined using a Precision Colorimeter NR20XE and expressed in the CIELAB dimensions of lightness ( $\mathrm{L}$ ), redness (a) and yellowness (b). After determining $\mathrm{pH}$ and colour measurements the same meat portions were cooked for 45 minutes at $71^{\circ} \mathrm{C}$ and allowed to cool for 10 minutes. Thereafter, Digital Firmness Tester Agrosta (R) 15 was used to measure meat tenderness.

The right breast and thigh meat portions were then boiled separately in unsalted water for 30 minutes and 25 minutes, respectively (Miezeliene et al., 2011). Samples were then allowed to cool for 10 to 15 minutes, deboned and cut into $1 \times 1 \times 1 \mathrm{~cm}$ cubes (Joubert, 2013) and thereafter presented to 96 untrained panelists. Meat samples were presented to untrained panelists together with a glass of water and the evaluation sheet. Evaluation sessions for breast and thigh meat were conducted on two separate days. The cooked right breast and thigh portions were subjected to sensory evaluation using a 9point Hedonic scale to determine overall liking and disliking of juiciness, flavour and acceptability of meat by consumers. In the 9 point Hedonic scale, 1 represented least point and 9 highest points (i.e., 9 points $=$ extremely like, 5 points $=$ neither like nor dislike, 1 point $=$ extremely dislike) Fanatico et al. (2007).

\section{Data analysis}

Meat colour, $\mathrm{pH}$ and tenderness were analysed using General Linear Model (GLM) procedures of the Statistical Analysis System (SAS Institute, 2009). Differences among breed means were compared by Duncan's Multiple Range test. The consumer panel sensory data were analysed with IBM Statistical Package for Social Sciences (SPSS) software (version 23) and descriptive statistics were used to obtain frequencies and percentages. Breast and thigh meat samples were accepted when the majority of the tasters showed results as at least, "like slightly" (value 6) and above in the Hedonic scale.

\section{RESULTS AND DISCUSSION}

\section{Meat quality}

\section{pH}

The thigh $\mathrm{pH}$ was significantly higher $(\mathrm{P}<0.05)$ in Orpington than Tswana chickens (Table 1). However, no 
Table 1. Meat quality attributes of Orpington and Tswana chickens reared under intensive system.

\begin{tabular}{lcccc}
\hline Category & Orpington & Tswana & SEM & P-value \\
\hline pH & & & & \\
Breast & 6.24 & 6.13 & 0.06 & 0.2736 \\
Thigh & $6.23^{\mathrm{a}}$ & $6.32^{\mathrm{b}}$ & 0.08 & 0.0211 \\
Colour & & & & \\
Breast & & & & \\
$\mathrm{L}^{*}$ & $65.72^{\mathrm{a}}$ & $63.12^{\mathrm{b}}$ & 2.47 & 0.0045 \\
$\mathrm{a}^{*}$ & 7.70 & 7.71 & 0.62 & 0.9595 \\
$\mathrm{~b}^{*}$ & 4.17 & 3.85 & 0.65 & 0.3205 \\
Thigh & & & & \\
$\mathrm{L}^{*}$ & 61.93 & 57.68 & 1.03 & 0.1506 \\
$\mathrm{a}^{*}$ & 12.77 & 13.46 & 0.39 & 0.4393 \\
$\mathrm{~b}^{*}$ & 9.33 & 7.32 & 0.50 & 0.1060 \\
Tenderness (N) & & & & \\
Breast & 11.51 & 14.63 & 1.09 & 0.2588 \\
Thigh & $7.38^{\mathrm{b}}$ & $10.58^{\mathrm{a}}$ & 0.55 & 0.0045 \\
\hline
\end{tabular}

SEM, standard error of the means; $L^{*}$, lightness; $a^{*}$, redness; $b^{*}$, yellowness.

$a, b$ Means in the same row with different superscript differ significantly $(P<0.05)$.

significant difference $(P>0.05)$ in breast muscle $\mathrm{pH}$ was found among the breeds. Previous study of Christiansen (2013) attributed the lower breast meat $\mathrm{pH}$ to variation in the concentrations of different muscle fibre types as white fibres have a higher glycolytic potential resulting in a lower pH. Husak et al. (2008) reported that higher meat $\mathrm{pH}$ is more effective for retaining desirable colour and moisture absorption properties. In agreement with Choo et al. (2014) who found lower pH value in meat from Korean local chickens compared to silky fowl, Tswana chickens in the current study had relatively lower breast meat $\mathrm{pH}$ than Orpingtons.

\section{Colour}

Breast meat from Orpingtons was lighter $(P<0.05)$ than Tswana chicken meat possibly due to genetic influence. Similarly, Christiansen (2013) found that breast and thigh meat from commercial broilers was lighter $(P<0.05)$ than breast and thigh meat from heritage bred or indigenous chickens. No significant $(P>0.05)$ difference in breast and thigh meat colour redness $\left(a^{*}\right)$, and yellowness $\left(b^{*}\right)$ of Orpington and Tswana chickens was observed (Table 1). Previous study by Sandercock et al. (2009) found that broilers have lighter breast muscle, and less red and yellow colour than the slower growing layer and traditional breeds. Meat colour is generally influenced by animal related factors such as the genotype and the age of animals (Fanatico et al., 2005a). Meat from older animals is darker due to increased myoglobin level with age. Meat colour can also be influenced by other management factors such as feeds and feeding systems (Fanatico et al., 2005a; Ponte et al., 2008).

Furthermore, Joubert (2013) explained that, animals natural behaviour is restricted under intensive production systems resulting in aggressive and dominance disorders which result in bruising and this may affect meat quality negatively. In this study, Tswana chicken meat had less colour values compared to Orpington possibly due to genetic influence. Choo et al. (2014) found the breast meat colour of three breeds of Korean local chickens to be significantly $(\mathrm{P}<0.05)$ lighter $\left(\mathrm{CIE} \mathrm{L}^{*}\right)$, redder $\left(\mathrm{CIE} \mathrm{a}^{*}\right)$, and yellower $\left(\mathrm{CIE} \mathrm{b}^{*}\right)$ than that of silky fowl. The difference in meat colour from this study compared to the study of Choo et al. (2014) could be due to the fact that birds used in this study were slaughtered at the same age while slaughter age differed in the previous study. In disagreement with current results, Husak et al. (2008) found no differences between meat colour of conventional and free-range products.

\section{Tenderness}

No significant $(P>0.05)$ difference in breast meat tenderness of Orpington and Tswana chickens was observed (Table 1). However, thigh meat of Tswana chicken was firmer $(\mathrm{P}<0.05)$ and needed more force to break through than Orpington meat (Table 1). The current result is in agreement with Jahan et al. (2005) and Grashorn and Serini (2006) who found that indigenous chicken meat is firmer than broiler meat. Meat tenderness is the most determining factor in meat acceptability 
Table 2. Meat acceptability of Orpington and Tswana chickens according to Panelists' age.

\begin{tabular}{lcccccc}
\hline \multirow{2}{*}{ Age } & \multicolumn{2}{c}{ Juiciness } & \multicolumn{2}{c}{ Flavour } & \multicolumn{2}{c}{ Overall acceptability } \\
\cline { 2 - 7 } & Orpington & Tswana & Orpington & Tswana & Orpington & Tswana \\
\hline$\leq 20$ & $5.1 \pm 0.22$ & $4.1 \pm 0.20$ & $4.9 \pm 0.30$ & $5.6 \pm 0.25$ & $5.3 \pm 0.20$ & $5.7 \pm 0.22$ \\
$21-30$ & $5.6 \pm 0.24$ & $5.4 \pm 0.20$ & $5.7 \pm 0.20$ & $5.3 \pm 0.20$ & $4.7 \pm 0.25$ & $5.3 \pm 0.44$ \\
$31-40$ & $6.3 \pm 0.37$ & $5.6 \pm 0.23$ & $4.6 \pm 0.30$ & $6.1 \pm 0.30$ & $5.1 \pm 0.20$ & $5.9 \pm 0.20$ \\
$41-50$ & $5.2 \pm 0.35$ & $5.0 \pm 0.30$ & $5.9 \pm 0.37$ & $6.4 \pm 0.33$ & $5.1 \pm 0.32$ & $5.8 \pm 0.32$ \\
$51 \geq$ & $6.2 \pm 0.44$ & $5.2 \pm 0.40$ & $5.5 \pm 0.24$ & $6.6 \pm 0.40$ & $5.8 \pm 0.22$ & $6.1 \pm 0.32$ \\
\hline
\end{tabular}

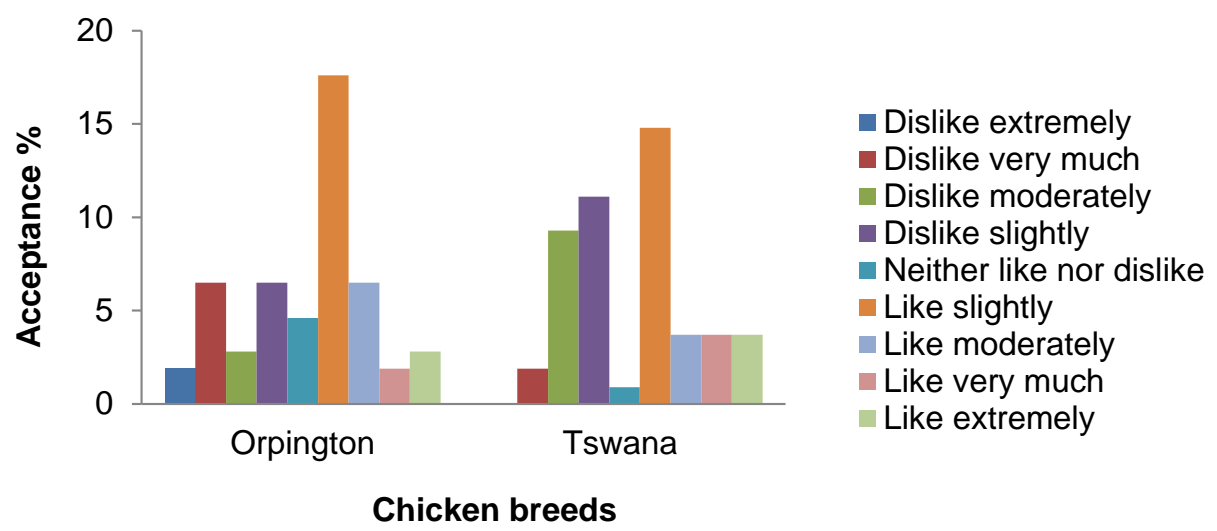

Figure 1. Consumer preference on breast meat juiciness.

(Strydom et al., 2000). Meat tenderness also depends on the type of muscle with the more tender meat being highly acceptable to consumers. Binda et al. (2012) found no significant difference in meat tenderness between the exotic chickens (Hybro and Hubbard) and native chickens (Bare- neck, Large Baladi and Betwil).

\section{Sensory evaluation}

\section{Consumer meat acceptability scores by age}

The mean scores given by consumers for the sensory characteristics by age are presented in Table 2. It seems from the present results that age of the consumers had an influence on their preferences for chicken meat. The age group of $31-40,41-50$ and $\geq 51$ gave Tswana meat higher scores for flavour and overall acceptability than Orpington meat. On the other hand, the middle age group of 31 to 40 years had higher mean scores on juiciness for the two chicken breeds, with the Orpington meat having higher scores for juiciness than Tswana chickens. Consumers aged 41 to 50 years and $>51$ years gave Tswana chicken meat had the highest scores for flavour and overall acceptability. This finding is in agreement with Dyubele et al. (2010) who observed that the perception of chicken meat is determined by the background of the consumers. Additionally, Kyarisiima et al. (2011) found that consumers' chicken meat preferences varied with age due to lack of exposure to exotic chicken meat consumption during their childhood.

\section{Juiciness}

According to the results on Hedonic scale of breasts meat juiciness, about $28.8 \%$ of consumers preferred or liked juiciness of Orpington chicken meat compared to $25.9 \%$ who liked juiciness of Tswana meat. Also, most of panelists $(22.3 \%)$ disliked meat juiciness of Tswana chickens compared to $17.7 \%$ of panelists who disliked Orpington meat (Figure 1). Furthermore, $50.8 \%$ of consumers liked Orpington thigh meat juiciness compared to $27.3 \%$ for Tswana chicken meat (Figure 2). In agreement with the present results, Choe et al. (2010) compared the quality characteristics between commercial Korean native chickens (KNC) and commercial broilers (CB) and found no significant sensory acceptance between the two genotypes. However, KNC had higher cohesiveness, chewiness and gumminess than $\mathrm{CB}$, the attributes that are indicative of a unique texture property. Juiciness is mainly affected by the water holding capacity and fat content of the meat (Aganga, 2003). The study of Fanatico et al. (2005b) found breast meat from slowgrowing birds to be too dry in just-about-right analyses. Similarly, Owens et al. (2006) found that significantly more consumers considered meat from the slow growing 


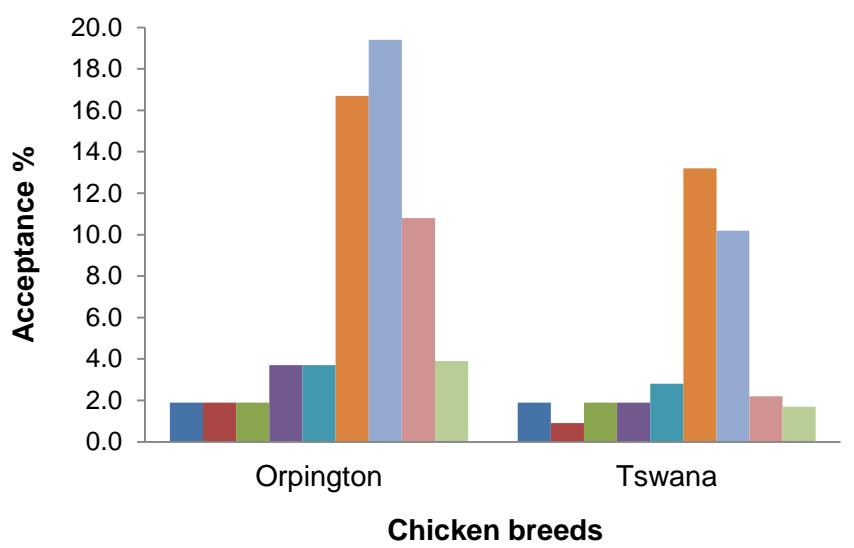

- Dislike extremely

- Dislike very much

- Dislike moderately

- Dislike slightly

- Neither like nor dislike

- Like slightly

- Like moderately

- Like very much

- Like extremely

Figure 2. Consumer preference on thigh meat juiciness.

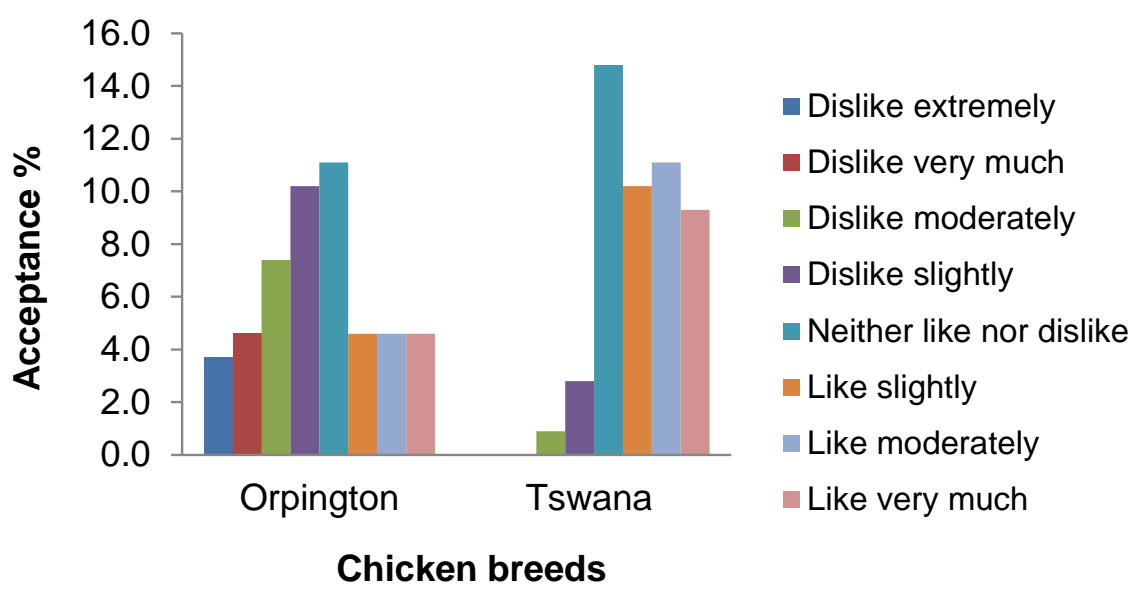

Figure 3. Breast meat flavour preference.

birds to be "much too dry" compared to the fast growing birds. Fanatico et al. (2007) explained that the lower juiciness of the slow growing genotype meat may also be related to the lower content of intramuscular fat.

\section{Flavour}

About $11 \%$ of the panellists classified the flavour of breast meat from Tswana chickens as 'like moderately' compared to $4.6 \%$ for Orpington chicken meat (Figure 3). As illustrated in Figure 4, 15.7\% of consumers slightly liked the flavour of thigh meat from Tswana chickens compared to Orpington (12\%). The current result is in agreement with Jahan et al. (2005) and Grashorn and Serini (2006) who found that indigenous chicken meat is firmer and more strongly flavoured than broiler meat. It is apparent that consumers in this study found the flavour development of indigenous chickens more palatable than the bland taste of broiler chicken meat. Fanatico et al. (2005b) attributed flavour development to the fact that indigenous chickens are slow growing than the fast growing broilers.

\section{Overall liking of meat}

As shown in Figure 5 , about $50 \%$ of consumers liked Tswana chicken meat compared to $20.9 \%$ for Orpington meat. No panellist disliked Tswana chicken meat compared to $21.4 \%$ of panelists who disliked Orpington meat (Figure 5). Islam (2000) argued that indigenous chicken meat and eggs are preferred by the majority of rural dwellers mainly because of their toughness, pigmentation, taste, leanness and suitability for special dishes. Similarly, Jahan et al. (2005), Jaturasitha et al. (2008), Walley et al. (2015) and Sokolowicz et al. (2016) observed that family chicken meat has unique characteristics such as low fat which makes it more ideal for the health conscious market. On the contrary, Owens et al. (2006) reported no differences in the overall liking and flavour of the breast meat or thigh meat between fast and slow growing birds. 


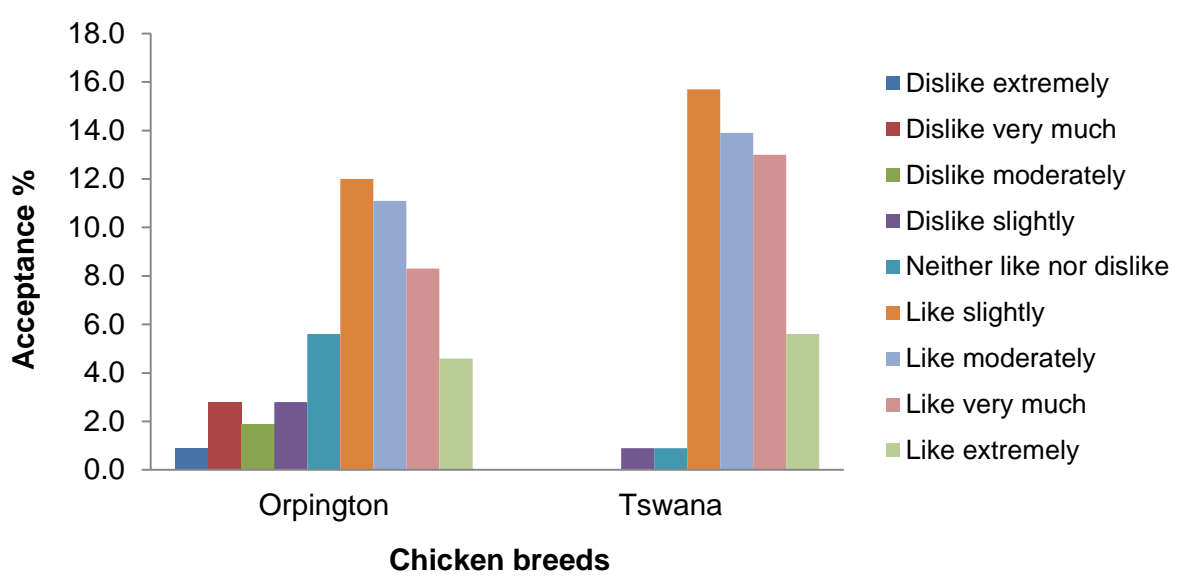

Figure 4. Thigh meat flavour preference.

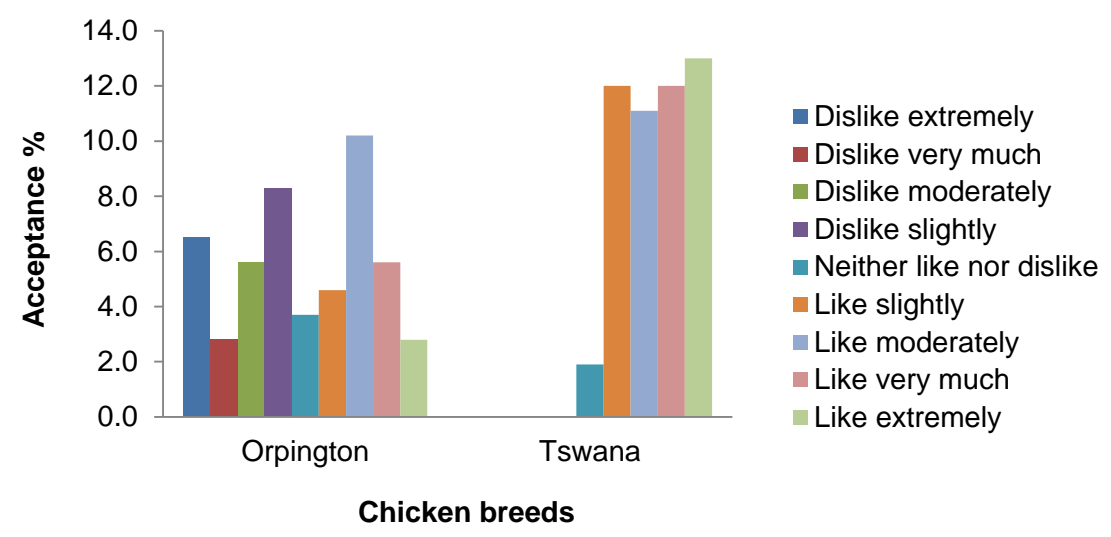

Figure 5. Consumers` overall acceptability.

\section{CONCLUSION}

Regardless of the type of chicken, breast meat had a lower $\mathrm{pH}$ than thigh meat. Again, breast meat was lighter $\left(L^{*}\right)$, less red $\left(a^{*}\right)$ and yellow $\left(b^{*}\right)$ than thigh meat. Meat from Tswana chickens was tougher than Orpington chicken meat. It seemed that the age of the consumers had influence on chicken meat preferences as consumers aged 41 to 50 years and above 51 years gave Tswana chicken meat the highest scores for flavour and overall acceptability. Sensory evaluation results showed Orpington meat to be juicier than Tswana chicken meat, however, most of consumers' preferred or liked flavour and accepted Tswana chicken meat than Orpington meat.

\section{CONFLICT OF INTEREST}

The authors declare that they have no conflict of interest.

\section{ACKNOWLEDGEMENTS}

We would like to express our thankful gratitude to the family of Radikara for financial assistance, BUAN for supplying experimental feeds, Ms. T. Petere, Messrs. B. Motlhanka and Mrs C. Nkomazana for their assistance in the feeding trials and meat sample preparation for sensory evaluation. We also thank the staff and students of BUAN for participating in consumer test.

\section{REFERENCES}

Aganga, A. A., Aganga, A. O., Thema, T., \& Obocheleng, K. O. (2003). Carcass analysis and meat composition of the donkey. Pakistan Journal of Nutrition, 2(3), 138-147.

Baeza, E., Chartrin, P., Meteau, K., Bordeau, T., Juin, H., Le Bihan-Duval, E., Lessire, M., \& Berri, C. (2010). Effect of sex and genotype on carcass composition and nutritional characteristics of chicken meat. British Poultry Science, 51(3), 344-353.

Berri. C., Le Bihan-Duval, E., Baeza, E., Chartrin, P., Millet, N., \& Bordeau, T. (2005). Effect of selection for or against fatness on muscle and meat characteristics of broilers. Journal of Animal Science, 85, 2005-2011.

Binda, B. D., Yousif, I. A., Elamin, K. M., \& Eltayeb, H. E. (2012). A comparison of performance among exotic meat strains 
and local chicken ecotypes under Sudan conditions. International Journal of Poultry Science, 11(8), 500-504.

Bogosavljević-Bosković, S., Kurcubic, V., Petrovic, M. D., \& Radovic, V. (2006). The effect of sex and rearing system on carcass composition and cut yields of broiler chickens. Czech Journal of Animal Science, 51(1), 31-38.

Choe, J. H., Nam, K., Jung, S., Kim, B., Yun, H., \& Jo, C. (2010). Differences in the quality characteristics between commercial Korean native chickens and broilers. Korean Food Science and Agricultural Resources, 30(1), 13-19.

Choo, Y. K., Kwon, H. J., Oh, S. T., Um, J. S., Kim, B. G., Kang, C. W., Lee, S. K., \& An, B. K. (2014). Comparison of growth performance, carcass characteristics and meat quality of Korean local chickens and silky fowl. Asia-Australasian Journal of Animal Science, 27(3), 398-405.

Christiansen, A. R. (2013). Nutritional, sensory, and quality attributes of heritage bred chicken and commercial broiler meat. Retrieved on 6th October 2015 from https://krex.kstate.edu/dspace/bitstream/handle/2097/16284/AlexandraChr istiansen2013.pdf?sequence $=1$.

Dyubele, N. L., Muchenje, V., Nkukwana, T. T., \& Chimonyo, M. (2010). Consumer sensory acceptability of broiler and indigenous chicken meat: A South African example. Food Quality and Preference, 21, 815-819.

Fanatico, A. C., Pillai, P. B., Emmert, J. L., Gbur, E. E., Meullenet, J. F., \& Owens, C. M. (2007). Sensory attributes of slow- and fast-growing chicken genotypes raised indoors or with outdoor access. Poultry Science, 86, 2441-2449.

Fanatico, A. C., Pillai, P. B., Cavitt, L. C., Owens, C. M., \& Emmert, J. L. (2005a). Evaluation of slower-growing broiler genotypes grown with and without outdoor access: Growth performance and carcass yield. Poultry Science, 84, 13211327.

Fanatico, A. C., Cavitt, L. C., Pillai, P. B., Emmert, J. L., \& Owens, C. M. (2005b). Evaluation of slower-growing broiler genotypes grown with and without outdoor access: Meat quality. Poultry Science, 84, 1785-1790.

Grashorn, M. A., \& Serini, C. (2006). Quality of chicken meat from conventional and organic system. Retrieved on 12th October 2015, from http://www.cabi.org/ Uploads/animalscience/worlds-poultry-science-association/WPSA-italy2006/10237.pdf.

Husak, R. L., Sebranek, J. G., \& Bregendahl, K. (2008). A survey of commercially available broilers marketed as organic, free-range, and conventional broilers for cooked meat yields, meat composition, and relative value. Poultry Science, 87, 2367-2376.

Islam, M. A. (2000). Effect of local and exotic strains of chicken for broiler production at hot humid climate. PhD Thesis, Institute of Animal Science, Faculty of Agriculture and Horticulture, Humboldt University of Berlin, Germany.

Jahan, K., Paterson, A., \& Piggott, J. R. (2005). Sensory quality in retailed organic, village and corn fed chicken breast. Food Research International, 38, 495-503.

Jaturasitha, S., Srinkanchai, T., Kreuzer, M., \& Wicke, M. (2008). Differences in carcass and meat characteristics between chicken indigenous to Northern Thailand (BlackBoned and Thai Native) and imported extensive breeds (Bresse and Rhode Island Red). Poultry Science, 87, 160169.

Joubert, S. (2013). The effect of genotype and rearing system on chicken meat quality. Retrieved on $19^{\text {th }}$ March, 2014, from https://scholar.sun.ac.za/bitstream/handle/10019.1/85783/jou bert_genotype_2013.pdf?sequence=1.
Kgwatalala, P. M., Nogayagae, M., \& Nsoso S. J. (2012). Growth performance of different strains of indigenous Tswana chickens under intensive management system. African Journal of Agricultural Research, 7(16), 2438-2445.

Kleczek, K., Wilkiewicz-Wawro, E., Wawro, K., \& Makowski, W. (2000). Effect of body weights of day-old Muscovy ducklings on growths and carcass traits. Archives Animal Breeding, 50(2), 204-213.

Kyarisiima, C., Naggujja, F. A., Magala, H., Kwizera, H., Kugonza, D. R., \& Bonabana-Wabbi, J. (2011). Perceived tastes and preferences of chicken meat in Uganda. Livestock Research for Rural Development, 23(11). Retrieved on $28^{\text {th }}$ October 2015 from http://www.Irrd.org//rrd23/11/kyar23242. htm.

Miezeliene, A., Alencikiene, G., Gruzauskas, R., \& Barstys, T. (2011). The effect of dietary selenium supplementation on meat quality of broiler chickens. Biotechnologie, Agronomie, Sociétéet Environnement, 15(1), 61-69.

Northcutt, J. K. (2009). Factors affecting poultry meat quality. Retrieved on $21^{\text {st }}$ September 2015, from http://www.thepoultrysite.com/articles/1312/factors-affectingpoultry-meat-quality/.

Owens, C., Fanatico, A., Pillai, P., Meullenet, J., \& Emmert, J. (2006). Evaluation of alternative genotypes and production systems for natural and organic poultry markets in the U.S. $12^{\text {th }}$ European Poultry Conference, Verona, Italy, 10-14 September, 2006, Paper 276.

Padhi, M. K. (2016). Importance of indigenous breeds of chicken for rural economy and their improvements for higher production performance. Review article. Scientifica, Article ID 26046785, 9 pages. Retrieved on $11^{\text {th }}$ April 2016, from http://dx.doi.org./10.1155/2016/2604685

Ponte, P. I. P., Rosado, C. M. C., Crespo, J. P., Crespo, D. G., Mourao, M. A., Chaveiro Soares, M. A., Bras, J. L. A., Mendes, I., Gama, L. T., Prates, A. M., Ferreira, L. M. A., \& Fontes, C. M. G. A. (2008). Pasture intake improves the performance and meat sensory attribute of free-range broilers. Poultry Science, 87, 71-79.

Sandercock, D. A., Barker, Z. E., Mitchell, M. A., \& Hocking, P. $M$. (2009). Changes in muscle cell cation regulation and meat quality traits are associated with genetic selection for high body weight and meat yield in broiler chickens. Genetics Selection Evolution Journal, 41, 8.

SAS Institute (2009). User's Guide Version, 9.2.1, 2002- 2009, SAS Institute Inc., Cary, NC, USA.

Sokołowicz, J., Krawczyk, J., \& Świątkiewicz, S. (2016). Quality of poultry meat from native chicken breeds - a review. Annals of Animal Science, 16(2), 347-368.

Strydom, P. E., Naude, P. T., Smith, M. F., Scholtz, M. M., \& van Wyk, J. B. (2000). Characteristics of village African cattle breed in relation to meat quality traits. Meat Science, 55(1), 79-88.

Walley, K., Parrot, P., Custance, P., Meledo-Abrahim, P., \& Bourdin, A. (2015). A review of French consumers purchasing patterns, perceptions and decision factors for poultry meat. World's Poultry Science Journal, 71, 5-14.

Weyuma, H., Singh, H., \& Megersa. M. (2015). Studies on management practices and constraints of back yard chicken production in selected areas of Bishoftu. Journal of Veterinary Science Technology, S12: S12-003. 